\title{
LATE MIOCENE CALCAREOUS NANNOFOSSIL STRATIGRAPHY AND BIOEVENTS CORRELATION: KALIDONIA CASE SECTION (NW CRETE, GREECE)
}

\author{
Bellas S. ${ }^{1}$, Frydas D. ${ }^{1}$, and Keupp H. ${ }^{2}$ \\ ${ }^{I}$ University of Patras, Department of Geology,26500 Rion/Patras,drbellas@zedat.fu-berlin.de, \\ Dfrydas@upatras.gr \\ ${ }^{2}$ Free University of Berlin, Department of Geosciences, Institute of Paleontology, Malteserstr. 74- \\ 100,D-12249Berlin,keupp@zedat.fu-berlin.de
}

\begin{abstract}
Calcareous nannofossils are widely used for biostratigraphic correlations. Quantitative approaches enable better understanding of reliability of bioevents. In order to refine the late Miocene stratigraphy of $\mathrm{NW}$ Crete, the deposits of Kalidonia basin along its type section are here investigated. It was possible to distinguish the Tortonian/Messinian boundary by NN11a \& NN11b, CN9a \& CN9b, MNN11a \& MNN11b biozones. Reticulofenestra pseudoumbilicus PB (Paracme Beginning) and $R$. rotaria FO (First Occurrence) proved to act as additional significant biohorizons improving the stratigraphic evolution of the studied paleobasin and providing a tight biochronologic framework. The Kalidonia section fully covers an undisturbed marine depositional cycle from the upper Tortonian to upper Messinian, where a predominant deep water facies (DWF) is followed by transitional sediments (TF) and the sequence closes at the top by a reefal-bioclastic facies $(R F)$ relative to the 'Calcare di Base' in Italy indicating the 'Messinian Salinity Crisis Event'.
\end{abstract}

Key words: Calcareous nannoplankton, biostratigraphic correlations, Tortonian, Messinian.

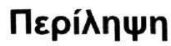

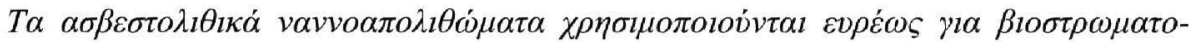

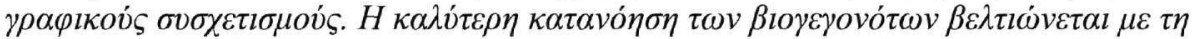

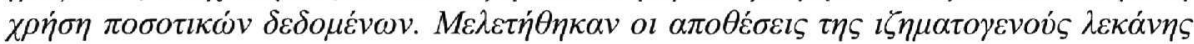

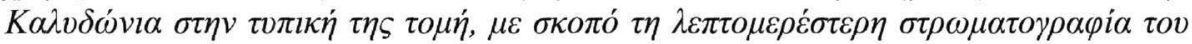

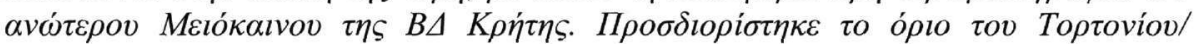

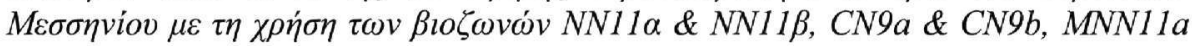

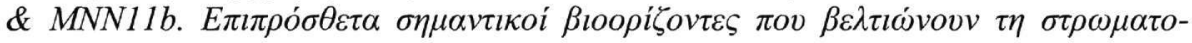

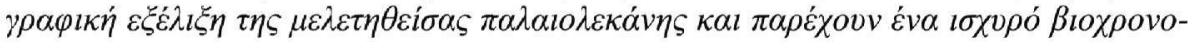

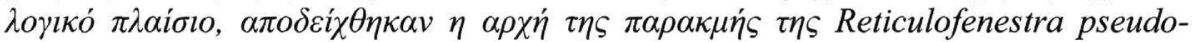

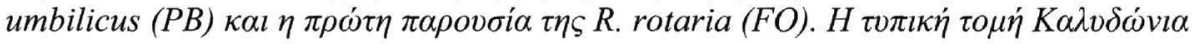

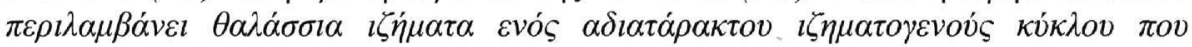
$\kappa \alpha \lambda u ́ \pi \tau \varepsilon l ~ \alpha \pi o ́ \theta \varepsilon \sigma \eta$ a

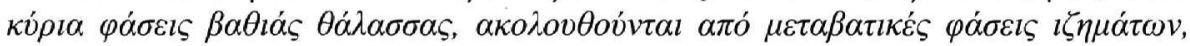

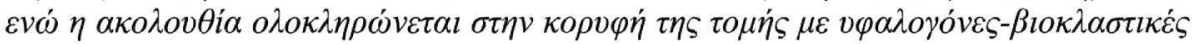




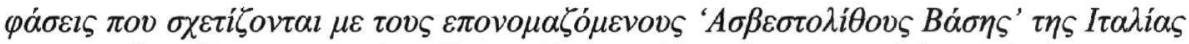

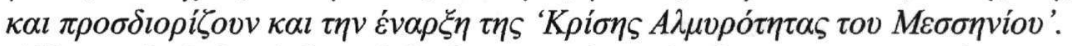

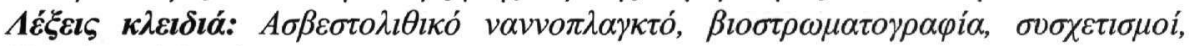

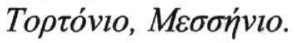

\section{Introduction}

The Hellenic Arc System, has been since long the subject of intensive research (McKenzie 1970, Makris 1978, Angelier 1979 Dewey and Sengör 1979 Mascle et al. 1982, Dixon and Robertson 1984). Generally it is believed, that southward retreat of the trench system induced migration of the arc itself, and gave birth and shape to the present-day Hellenic Arc System configuration (Wortel and Spakman 1992). The extension in the Aegean Sea (especially at the southern part of it) and the southward movement of Crete Island was caused by the rollback effect of the slab and the broad subduction zone (Le Pichon 1982, Meulenkamp et al. 1988, 1994). This rollback process of the Hellenic subduction zone started about 12 my ago (Meulenkamp et al. 1994). Furthermore, the active tectonics deformation of the Aegean region itself is dominated not only by extensional but by combined strike-slip motions and compressional tectonics as well (Jackson 1994, Meulenkamp et al. 1988). The concentration of slab pull forces causes a pattern of subsidence (combined with depocenters development) and uplift migrating along strike. Subsequently prevailed a maximum crustal thinning and subsidence in the region of Cretan Sea produced the back-arc basin(s) at the north of Crete as it was firstly suggested by studies of Makris (1978) and Angelier et al. (1982) and recently by Wortel and Spakman (2000).

The Neogene basins of northwestern Crete are generally considered the result of the prementioned subsidence. NNE- and WNW- trending fault systems, which were developed during the middle Miocene, represent the dominant structural feature controlling the configuration of these basins. Sedimentary deposition commenced at most if not at all of them during either the middle or the early late Miocene interval, usually at the Serravallian or the lower Tortonian respectively (Freudenthal 1969, Meulenkamp et al. 1979, Keupp and Bellas in collab. with Frydas and Bartholdy 2000).

Based on recently published integrated bio-, cyclo- and magnetostratigraphic schemes dealing with the late Miocene deposits of Mediterranean, this work aims firstly to present a tight biostratigraphy of the Kalidonia section located between Kolymbari and Kastelli town at the northwestern Crete Island. A refinement of the existing biostratigraphy will be further discussed. The Kalidonia section is considered the "type section" of Kalidonia basin (Keupp and Bellas in collab. with Frydas and Bartholdy 2000, this work). In addition to the Potamida section ("representative section" of Kissamou Formation after Freudenthal 1969) and due to the good material quality, exposure possibilities (easy access, undisturbed sequences) and preservation of the microfossils and nannoflora, Kalidonia is also considered as a subtypus locality for the Deep Water Facies (DWF), former "Kissamou Formation". The variability of paleodepositional environmental conditions prevailed in Kalidonia basin during the late Tortonian to late Messinian time span is lithostratigraphically demonstrated. Furthermore, the reliability of some known biohorizons of calcareous nannofossils has been evaluated along the studied section and their applicability concerning the biochronological correlation in the eastern Mediterranean Sea has been discussed and commented. For this purpose, we have used semiquantitative data of calcareous nannofossils.

\section{The study area in the Neogene}

The Kalidonia Basin is a small sedimentary basin (or subbasin), located on the NW Crete and situated directly on the foot of Rodopou peninsula (Fig. 1). Geologically, the Kastelli and Maleme (or Voukolies) Basins bound this basin to the west and to the east respectively (Keupp and Bellas in collab. with Frydas and Bartholdy 2000). Pre-Neogene strata, mostly represented by the P-Q 
Group (Phyllites-Quartzites) separate the neogene successions of Kalidonia Basin, by those of the other basins. Remnants of neogene littoral deposits of Kalidonia have been mapped along the Rodopou peninsula at various altitudes. It has been postulated that syngenetic formation of horst (uplifted blocks where erosion predominates) and graben structures (downfaulted areas where sediments accumulate) modified an initially rather uniform depositional area of NW Crete (Frydas et al. 1999). Despite this isolation and the small size, the Kalidonia basin and its Neogene strata present a similar to the other Cretan basins lithostratigraphic facies and biostratigraphic history (i.e. Meulenkamp et al. 1979), pointing to a rather common development of them all.

Four sedimentary formations of Neogene age have been recognized in the broader area of Plakalona, namely the Mesonisi, Roka, Cherethiana and Kissamou (sensu Freudenthal 1969). In general the Neogene strata have been distinguished into two major groups based on their depositional environment, a) the non-marine and b) the marine facies. The Mesonisi Formation belongs to the terrestrial-fluviatile facies, which was not encountered in the studied section. Miocene and Pliocene age deposits firstly recognized in NW Crete by means of foraminifera by Christodoulou (1963) and later on were studied by Dermitzakis and Markopoulou-Diakantoni (1979), Meulenkamp et al. (1979) and Schmidt (1979). According to Kontopoulos et al. (1996) the Neogene strata of NW Crete were distinguished in two depositional

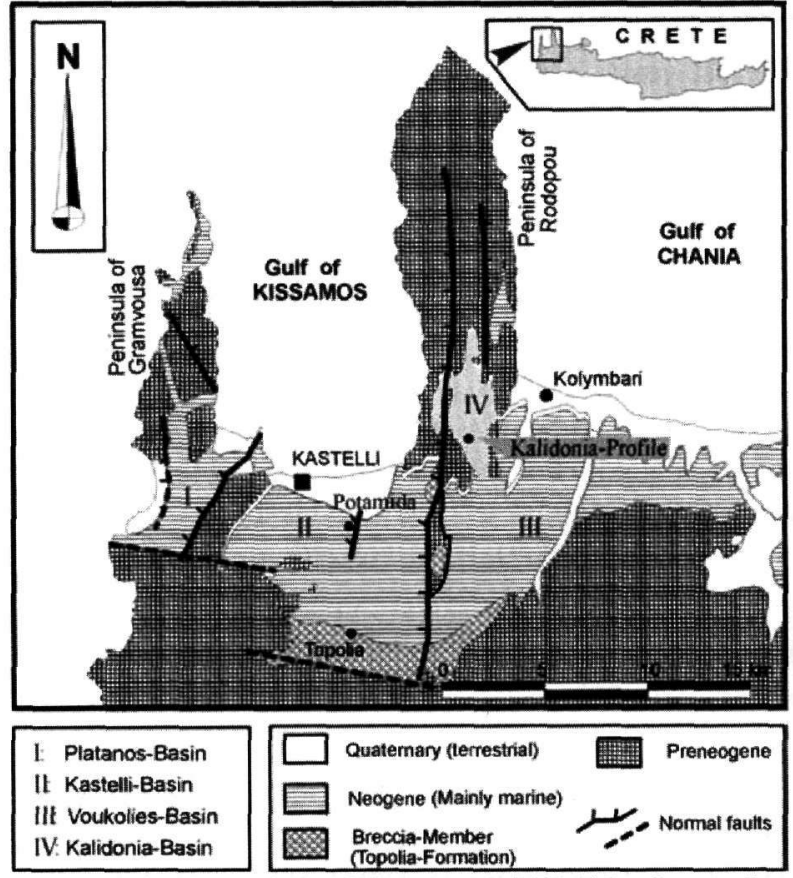

Figure 1 - Location of the studied Kalidonia section in NW Crete Island sequences, the Miocene Sequence A and the Pliocene Sequence B, or the so-called First Miocenic Cycle and the Second Pliocenic Cycle (Frydas and Keupp 1996). The present study allows us to affirm that the sediments of the Kalidonia basin belong to the first and older depositional sequence (i.e. the Miocenic Cycle).

\section{Material and Methods}

Kalidonia section is located on the new national road connecting Kolymbari village and Kastelli town (Fig. 1). Samples of soft sediment were collected for biostratigraphic analyses at an average distance of 0.90 meters. In other studies of ODP for similar purposes, considering biostratigraphy and palaeoecology, resolution of ca. 1.0-1.5m was judged good enough. In our case decompaction was not taken into account. Micropaleontology was mainly based on the calcareous nannofossils identification under both the normal light (at magnifications of ca. 1000x) and the scanning electron microscope (SEM.). Smear slides preparation followed standard techniques. In a preliminary publication, the planktonic foraminifera of Kalidonia section were also studied and some of the key species were reported and illustrated, but as subordinates to the nannoflora (compare Plate 2 in Frydas et al. 1999). The biostratigraphic schemes used are the "standard" zones of Martini (1971) and Okada and Bukry (1980). Additional useful bioevents and their biochronological calibration are based on Theodoridis (1984), Martini and Müller (1986), Young 
et al. (1994), Raffi and Flores (1995), Fornaciari (2000), Lourens et al. (2004) and Raffi et al. (2003, 2006). A quantitative and subsequently semiquantitative study using the calcareous nannoplankton has been also performed. Quantification of species presented in Table 1, based on the following pattern: $\mathbf{A}$ (Abundant) $=>20$ individuals (measuring 100 specimens), $\mathbf{C}($ Common $)=$ $11-20, \mathbf{F}(\mathrm{Few})=6-10, \mathbf{R}($ Rare $)=2-5$ and $\mathbf{P}$ (Present $)=1$ individual $/$ smear slide .

\section{Results}

\subsection{Lithostratigraphy and biofacies}

In the last years, a new concept concerning facies and sedimentary architecture for the neogene deposits of NW Crete has been developed. Therefore, facies terminology of the present work and their subdivision in broad follows that of Frydas and Keupp (1996), Bellas et al. $(1998,2000)$ and Keupp and Bellas in collab. with Frydas and Bartholdy (2000).

According to this concept three mainly depositional lithofacies, which compose the ca. 32 meters thick Kalidonia section, are recognized in the studied section (Fig. 2):

Unit-1. (Deep Water Facies or -DWF-). At the base, grey, amorphous, homogenous, slightly sandy marls about 17 meters thick, are overlain by 8 meters of slightly laminated marls and claystones of middle/outer shelf to slope or mesopelagic environment. When alternate, the former marls are generally considered to correspond to insolation minima, while the later one to insolation maxima (Krijgsman, et al. 1999). This facies is correlated to the former "Kissamou Formation" after Freudenthal (1969). It is followed upwards by:

Unit-2. (Transitional Facies or -TF-). Yellowish sandy marls ( 2 meters thick) and a sandstone bank (1 meter thick), point to the transition from shelf sediments to shallow-water, neritic environment. The TF is correlated to the former "Cherethiana Formation" after Freudenthal (1969).

Lithofacies of Unit-2 exhibits important fossil elements, like Brachiopods of the Genus Terebratula sp., abundant Pectenidae and a significant biohorizon of the benthic foraminifer Heterostegina sp.. Freudenthal (1969) firstly reported on the Heterostegina massive banks of the former "Roka Formation". However, the later occurrences are referred to the transgressive littoral facies LF-A (LF-At, $\mathbf{t}$ for transgressive) and characterize the basal neogene sediments (in our case of Tortonian age) deposited in the NW Crete basins, while the frequent occurrences of Heterostegina bioevent recorded in Unit-2 of Kalidonia section, are referred to the regressive littoral facies LF-A (LF-Ar, $\mathbf{r}$ for regressive) or to the TF of the above basins and depict a precommence of the so-called "Messinian Event" of middle-upper Messinian age.

Unit-3. (Reefal-bioclastic Facies or -RF-). The section closes at the top with a caprock consisting of the recently described reefal-bioclastic limestones facies, which is placed in the upper, regressive, littoral facies Type A (part of LF-A, in Bellas et al. 1998).

The RF in Kalidonia (Unit-3) is about 3.5m thick and it is partly correlated to the former "Roka Formation" after Freudenthal (1969). It is rich in macrofossils like Corallinaceae (Lithothamnium), scleractinian Corals (Tarbellastraea sp., Porites sp.), Tentaculats (cyclostome Bryozoa, Terebratula sinuosa), Cirripeds (Pyrgomma sp.), Molluscs (Glycimeris sp., Lithophaga sp., diverse pectinids and molds of gastropods), and Echinoids (Schizechinus sp., Clypeaster sp.). The RF is characteristic for deposition during onset of the well-known Mediterranean Messinian Salinity Crisis, which mainly affected the margins and the highly uplifted blocks (Plakalona case) of the basins in the studied area. Similar marine algal limestones were reported from the marginal Late Messinian Sea in Spain, Tunisia, western Sinai and central Crete (Sonnenfeld 1985, our unpublished data). 


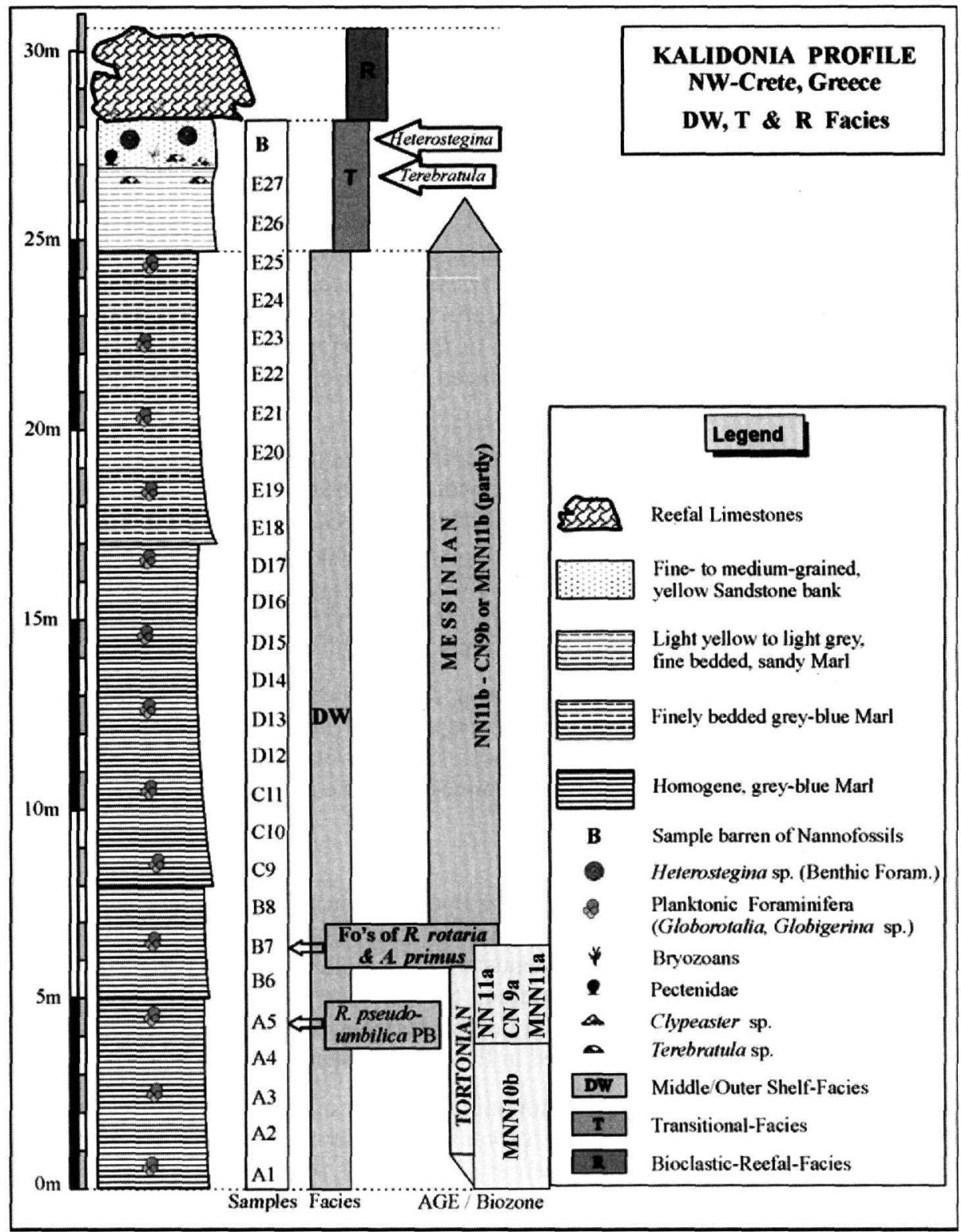

Figure 2 - Lithostratigraphy, facies and key biostratigraphic events of calcareous nannofossils along Kalidonia section

The whole succession of the three above-mentioned litho-biofacies generally points to a regressive sequence, developed from deep marine at the base (Unit-1), to shallow-water (Unit-2) and further to pure littoral deposits at the top (Unit-3). It belongs to the first sedimentation cycle (A) of Late Miocene age (Frydas and Keupp, 1996; Kontopoulos et al. 1996).

\subsection{Calcareous nannofossils biostratigraphy}

\subsubsection{Late Miocene calcareous nannofossil biozones}

According to the preliminary study (based on a first set of five samples) of the calcareous nannofossils of Kalidonia section (Frydas et al. 1999, Keupp and Bellas in collab. with Frydas and 
Bartholdy 2000), their association was placed in the CN9 biozone (= Discoaster quinqueramus) sensu Okada and Bukry (1980) "Low-latitude biostratigraphic zonation", or to the equivalent and homonymous of it NN11 zone of "Standard Nannofossil Zonation" (Martini 1971). The latter zone was primary defined on the basis of the total range of $D$. quinqueramus.

Okada and Bukry (1980) subdivided the CN9 Zone in CN9a and CN9b by use of Discoaster berggrenii and/or Discoaster surculus occurrences. Martini and Müller (1986) also subdivided the NN11 in NN11a and NN11b, by the presence of Amaurolithus delicatus at the base of the last subzone. Theodoridis (1984) developed another biozonation scheme for the Mediterranean Miocene CN9 Zone, where three zones (Coccolithus pelagicus, Amaurolithus primus and Reticulofenestra rotaria) and one subzone (Calcidiscus leptoporus Zone MA) were distinguished. First Occurrence of $A$. primus defined the base of the homonymous species Zone, while a small interval (that of $R$. rotaria Zone) was introduced by presence/disappearance of this species (base/top of homonymous Zone).

A further attempt to biostratigraphically refine the important stratigraphic period of Late Miocene was made by Raffi and Flores (1995). They subdivided the CN9b into three parts; CN9bA, CN9bB and CN9bC, by using the FO and LO of Amaurolithus amplificus (now Nicklithus amplificus sensu Raffi et al., 1998) as defining the base and top of CN9bB. According to recent studies by Hilgen $e t$ al. (2000), the Amaurolithus amplificus s.s. FO postdates the Tortonian/ Messinian (T/M) boundary. Since this species was not identified in the studied samples (compare also Fornaciari, 2000), the above tripartite subdivision of CN9b is not applicable in this paper.

Recently, Raffi et al. (2003) proposed for the upper Miocene five out of seventeen selected biohorizons of calcareous nannofossils as easily reproduced in the Mediterranean and out of it, which as they stated, were also considered useful for correlations to worldwide stratigraphy. Among them, four could be incorporated and commented in the present study.

\subsubsection{Biostratigraphic results}

The calcareous nannofossils of the Kalidonia section are generally well preserved, comprising a total of 47 different species, but are represented in low abundances. In the upper part of the section, due to the littoral character of the deposits (TF; samples E25-E27), the assemblage is not considered original. Late Miocene most important taxa have been identified and reported in Table 1. In the following it will be commented on key biohorizons of selected species from Kalidonia section, as they have been mainly recognized in E. Mediterranean by Raffi et al. $(2003,2006)$.

Discoaster pentaradiatus is exceptionally found common in only one sample by the base of the Kalidonia section; otherwise, this species is sporadically present and generally occurs in very low abundances. Therefore, the proposed by Raffi et al. (2003) D. pentaradiatus FCO (First Common Occurrence), defining the base of Zone MNN10b, is not recognized in the present work.

Both, D. berggrenii and D. quinqueramus, the key species of CN9 Zone, are present along the section (samples A1 to E24) although inconsistently.

The Reticulofenestra pseudoumbilicus PB is easily recognizable and can be placed at the stratigraphic level of samples interval A4 to A5, where the species after a constant presence from the base of the section upwards (samples A1 to A5), disappears or after a small recover in samples $\mathrm{B} 7$ and $\mathrm{B} 8$, is simply present as rare specimens to the top of the section.

In Kalidonia section, first Amaurolithus, although rare, together with $R$. rotaria, have been both recorded at the level of sample B7 onward (Table 1), therefore indicating the $\mathrm{CN} 9 \mathrm{a} / \mathrm{CN} 9 \mathrm{~b}$, NN11a/NN11b and MNN11a/ MNN11b subzonal boundary and subsequently the T/M boundary.

These nannofossil events make possible an important assignment of the lower part of Kalidonia section (samples A1-B6) at the upper Tortonian zones NN11a/CN9a, while the sediments which bound sample B7 to the Tortonian/ Messinian boundary and the rest of the succession is placed to 
the lower Messinian zone NN11b/CN9b (samples B7 to E24). R. pseudoumbilicus size ranged from greater than $8 \mu \mathrm{m}$ at the base, to less than $7 \mu \mathrm{m}$ at the top and the scarcity of it upsection, are additional bioevents that also support our previous results (co. also Young 1990, Huang 1997). The T/M boundary coincides with sample level B7. Lithostratigraphically, above sample E24 sedimentation firstly changes to littoral type and later commences a transition (TF) to the RF deposition, pointing to the onset of the salinity crisis Messinian event in the Mediterranean. The RF facies relatively corresponds to the base of the 'Calcare di Base' dated at $5.95 \mathrm{Ma}$ by Hilgen et al. (1995) or at 5.96 \pm 0.02 Ma by Krijgsman et al. (1999).

Summarizing, the following bioevents of calcareous nannofossils are well documented and provide a useful and reliable stratigraphical framework applicable to the Kalidonia section. They are listed from the base of the section onwards below. a) Occurrence of both $D$. berggrenii and $D$. quinqueramus (NN11a, CN9a), b) common occurrence of $R$. pseudoumbilicus, followed by c) PB (paracme beginning) of it (base of MNN11a), d) Common FO's at the same stratigraphic level of both $A$. primus and $R$. rotaria ( T/M boundary and NN11b, CN9b, MNN11b) and e) almost consistent presence of $D$. quinqueramus to the section upward and possible top occurrences of both $D$. berggrenii and $D$. quinqueramus (E24 sample). It follows an almost barren interval of calcareous nannofossils, prior to the Reefal Facies (RF) development at the top of the section.

\section{Discussion}

Considering the Kalidonia section, $D$. berggrenii was observed in low abundances at the base of the Kalidonia section and $D$. quinqueramus was simply present in the samples of the section upwards to the top. As Wei (2003) pointed out, major disagreements exist on the taxonomical concepts used by various authors for these species. Both of them characterize the NN11/CN9 zone of calcareous nannofossils. The ages of $8.5 \mathrm{Ma}$ and of $8.2 \mathrm{Ma}$ were assigned to the FO datums of D. quinqueramus and D. berggrenii berggrenii respectively (EXXON core in the Gulf of Mexico, Wei, 2003). The datum of the top of $D$. berggrenii roughly calibrated at $\sim 6.2 \mathrm{Ma}$ by the previous author. The D. quinqueramus-berggrenii intergrade appears slightly later (is relatively younger in age). It is reported by Rio et al. (1990) to have gradationally evolved from Discoaster bellus (Young et al. 1994). The D. bellus is inconsistently represented in low abundances along the section. Based on the specimens' rarity and preservation state, we consider at least the uppermost two occurrences of them to be reworked (samples E24 \& E25).

Since $D$. pentaradiatus occurs sporadically and in very low abundances along Kalidonia section, its FCO (calibrated at 9.37 Ma by astronomically induced sedimentary cycles by Raffi et al. 2003) cannot be identified. Obviously this event stratigraphically predates commence of deposition of the section basal layers in Kalidonia basin.

According to Raffi et al. (2003, 2006) and Lourens et al. (2004), the event of R. pseudoumbilicus PB (Paracme Beginning) characterizes the base of Zone MNN11a, with an absolute age of 8.76 or 8.71 Ma respectively. Young (1998), Fornaciari (2000), Kameo and Bralower (2000) and Marino and Flores (2002) report on this event too. According to the latter, this paracme interval incorporates the base of NN11b, although others place it to the upper part or only the base of CN8b (Fornaciari 2000, Kameo and Bralower 2000). We have also identified the paracme interval of $R$. pseudoumbilicus in the Potamidha section of NW Crete (Schmidt 1979: fig. 1, p. 169, 188), where it is obvious that the abundance of this species dramatically reduces at the upper stratigraphic intervals to the top of the section (late part of II, III and IV). This is well correlated with the interval starting with the so-called $R$. pseudoumbilicus PB by Raffi et al. (2003).

The reliability of events related to the genus Amaurolithus was confirmed by Negri and Villa (2000) for Cretan sections, as well as by Raffi et al. $(2003,2006)$ on a combined study of various sections and holes. Amaurolithus spp. and/or A. primus FO (First Occurrence) biohorizon is equivalent to the base of Subzone MNN11b and it is calibrated at 7.46-7.47 Ma (Qued Akrech 
section of Morocco; Hilgen et al. 2000), at 7.430-7.435 Ma (Faneromeni section of SE Crete; Negri and Villa 2000), or somewhat younger at 7.424 Ma (E. Mediterranean; Raffi et al. 2006). These species FO's slightly predate the Tortonian/Messinian (T/M) boundary in Mediterranean Neogene. They are the closest nannofossil bioevents corresponding to the T/M boundary, which is defined by the FAD of the foraminifera grouped as Globorotalia conomiozea. The T/M boundary level in Morocco was astronomically dated at 7.251 Ma, found in the middle of the reversed Subchron C3Br.1r (Hilgen et al. 2000). According to these authors, all above Amaurolithus group events (including the $A$. delicatus FO, not mentioned here), predate the T/M boundary and are considered "extremely useful" to delimit it on a global scale. The T/M datum in the Mediterranean was initially placed at 7.24 or at $7.12 \mathrm{Ma}$ by Hilgen et al. (1995) and Krijgsman et al. (1995) respectively, but recently it has been dated at 7.246 Ma (Lourens et al. 2004, Raffi et al. 2006).

Raffi et al. (2003) stated that the $R$. rotaria FO and FCO are not reliable events, not improving the biostratigraphic resolution by calcareous nannofossils. Despite that, Negri and Villa (2000) had pointed out the usefulness of this event, especially in onland sections, like that of Faneromeni in SE Crete and considering the nannofossil events across the Tortonian/Messinian boundary. $R$. rotaria is a circular but distinctive variant of $R$. pseudoumbilicus, relatively easy to identify and it is reported from CN9b subzone by many authors like Theodoridis (1984), Flores et al. (1992), Young (1994), Bellas et al. (1998, 2000), Siesser and Kaenel (1999), Duermeijer et al., (1999), Hilgen et al. (2000), Keupp and Bellas, in collab. with Frydas and Bartholdy (2000) and Raffi et al. $(2003,2006)$. It is true that $R$. rotaria may not be always present (or better identified) in all studied sections in the Mediterranean till now, however if it is recognized once, then is very important as biohorizon (proved both in Faneromeni and in present case of NW Crete onland sections). Notably, the FO and the FCO of $R$. rotaria are differently dated at 7.421 and $7.264 \mathrm{Ma}$ respectively (Negri and Villa 2000) or recently at 7.41 and $7.24 \mathrm{Ma}$ (Lourens et al. 2004). Therefore, $A$. primus $\mathrm{FO}$ predates the occurrence of $R$. rotaria by a difference of $\sim 0.01 \mathrm{Ma}$. In our samples set, $A$. primus and $R$. rotaria occur both at the same stratigraphic level (sample B7). It seems that the samples resolution interval along Kalidonia section (ca. $0.90 \mathrm{~m}$ ) was low and not enough to distinguish these events from one another. Hilgen et al. (2000) study of the classic Messinian Moroccan Oued Akrech section (Atlantic Morocco), correlated A. primus FO with an age ranging between 7.470 and $7.466 \mathrm{Ma}$, dates which are obviously older than those obtained from eastern Mediterranean (7.424 Ma according to Raffi et al. 2006). According to Theodoridis (1984: 48, fig. 44), the occurrence of $R$. rotaria can be in part correlated to the lowermost part of the CN9b subzone of Okada and Bukry (1980), a fact further supporting our data.

\section{Conclusions}

The Kalidonia section, a type profile of the Neogene Kalidonia sedimentary basin was used for a biostratigraphic study of late Miocene deposits in the eastern Mediterranean Sea. New nannofossil data and development of the science (integration of magneto-, cyclo-, and biostratigraphy) make easier the age calibration of Kalidonia as well as correlations with assignments of bioevents from the Mediterranean and the Atlantic Morocco where major disturbance took place at the entrance of the ocean water to the Mediterranean during most of the upper Messinian.

The calcareous nannofossil distribution pattern is well documented. It shows a high paleobiodiversity and good preservation but scarcity of the key species in the Deep Water Facies (DWF, Unit-1). Presence from the base upwards of $D$. berggrenii and $D$. quinqueramus defines the NN11 or the equivalent of it CN9 Zones of Upper Miocene age for the studied section. Both species range almost to the top, where due to factors of sensitivity to carbonate dissolution in shallowwaters they disappear (Transitional and Reefal Facies, TF \& RF, Units -2, -3). 


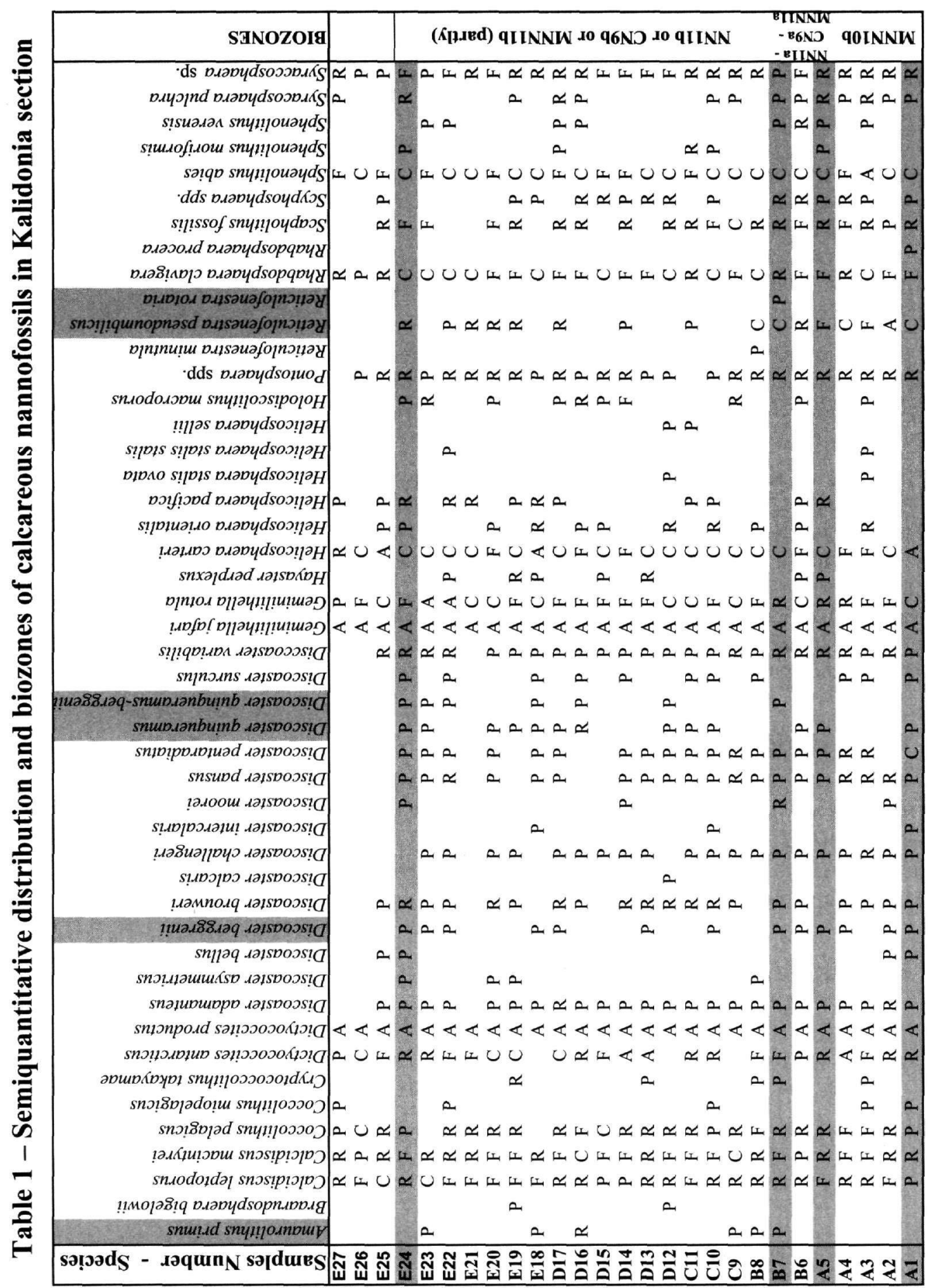


In Kalidonia section the interval starting with the $R$. pseudoumbilicus PB bioevent (Paracme Beginning) is easily recognizable and can be placed at the stratigraphic interval between samples (s.) A4 and A5 (located at ca. 4-5 meters from the base of the section upwards). This event marks the base of MNN11a subzone. It is dated and astronomically calibrated at $8.761 \mathrm{Ma}$, well correlated with that proposed by Raffi et al. $(2003,2006)$ for the Mediterranean Sea. Large Reticulofenestra $(>7 \mu)$ specimens were never fully recovered. Reappearance of this species was rare and inconsistent up to the top of the section (Table 1).

Integrated biostratigraphy correlate the $\mathrm{FO}$ of $A$. primus (including the Amaurolithus spp.) and that of $R$. rotaria. It is possible to find both events at the same stratigraphic level together, due to close ages of both biohorizons (7.42 and 7.41 Ma respectively, Lourens et al. 2004, Raffi et al. 2006) if sampling resolution is low as in our case. In the above context, the lowermost part of Unit-1 (s. A1-A4) is placed in the upper part of MNN10b subzone. The calcareous nannofossil assemblage of s. A5 to B6 is biostratigraphically placed in the CN9a (or the equivalent NN11a, MNN11a) subzones, while the upper part of Unit-1 (s. B7 to E24) is placed in the CN9b (or the NN11b, MNN11b) subzones.

The commencement of sedimentation in Kalidonia basin cannot be exactly evaluated but it can be placed in the time interval between $9.37 \mathrm{Ma}(D$. pentaradiatus $\mathrm{FCO})$ and $8.761 \mathrm{Ma}(R$. pseudoumbilicus PB), being closest to the latter datum. Deep water sedimentation in the basin lasted to about 6.1-6.2 Ma (D. berggrenii berggrenii top or LO datum, located at level of sample E24).

The caprock of Kalidonia section consists of bioclastic, karstified limestones and coral-reef remnants. Considering the base of this reefal facies (RF), which characterizes the synchronous onset of the Messinian salinity crisis (Krijgsman et al. 1999), relatively equivalent to the 'Calcare di Base' in Italy, an age of ca. $5.960 \pm 0.02$ Ma can be inferred. Subsequently the Units-1 and -2 of Kalidonia section (measuring 28 meters in thickness, including compaction) cover deposition between 3.41 and $2.80 \mathrm{Ma}$, plus the unknown time demand for development of the RF (regressive Unit-3). An average sedimentation rate of ca. $1.11 \mathrm{~cm} / \mathrm{kyr}$ is calculated for the deposition of the lower two lithostratigraphic units in Kalidonia basin during the Late Miocene.

\section{Aknowledgments}

The DFG (Deutsche Forschungsgemeinschaft) is specially thanked for financial support to H.K. and S.B., while the latter was Research Assistant in Berlin. FU-Berlin (Free University, Paleontology Institute) permission was necessary for laboratory and instrumental (S.E.M.) research work. Mrs. A. Hoernig-Pint helped a lot in the field during her Diplom-work. Review comments by M. Triantaphyllou (Athens) and A. Di Stefano (Catania) improved the original manuscript.

\section{References}

Angelier, J., 1979. Néotectonique de l'arc égéen, Soc. Géol. Nord, Spéc. Publ., 3, 418pp.

Angelier, J., Lyberis, N., Le Pichon, X., Barrier, E., and Huchon, Ph., 1982, The tectonic development of the Hellenic arc and the sea of Crete: a synthesis, Tectonophysics, 86, 159-196.

Bellas, S., Keupp, H., and Frydas, D., 1998a. The first Neogene (Upper Miocene) marine Transgressional-Regressional cycle of NW. Crete. Evidence based on sedimentologic and biostratigraphic data, $15^{\text {th }}$ Intern. Sedimentol. Assoc. Conf. (IAS98), Alicante/Spain, 13-17 April, 182-183.

Bellas, S.M., Keupp, H., and Frydas, D., 2000. Nannofossil biostratigraphy of the Late Miocene marine sedimentary sequences from NW Crete Island, Greece, Spec. Publ. Geol. Soc. Greece, 9, 9-18. 
Christodoulou, G., 1963. Geologische und mikropalaeontologische Untersuchungen im Neogen der Insel Kreta, Habilitation, Athens, University of Athens, 157pp.

Dermitzakis, M.D., and Markopoulou-Diakantoni, A., 1979. Stratigraphy and macrofauna of the Neogene deposits in Kastelli Kissamou district (W. Crete), VIIth International Congress on Mediterranean Neogene, Athens 1979, Ann. Géol. Pays Hell., hors série, A, 1, 317-328.

Dewey, J.F., and Sengör, A.M.C., 1979. Aegean and surrounding regions: complex multiplate and continuum tectonics in a convergent zone, Bull. Geol. Soc. Am., 90, 84-92.

Dixon, J.E., and Robertson, A.H.F., 1984. The geological evolution of the eastern Mediterranean, Geological Society Spec. Publication, 17, London, Blackwell, 824pp.

Duermeijer, C.E., Krijgsman, W., Langereis, C.G., Meulenkamp, J.E., Triantaphyllou, M.V., and Zachariasse, W.J., 1999. A Late Pleistocene clockwise rotation phase of Zakynthos (Greece) and implications for the evolution of the western Aegean arc, Earth Planet. Sci. Lett., 173, 315-331.

Flores, J.A., Sierro, F.J., and Glacon, G., 1992. Calcareous plankton analysis in the pre-evaporitic sediments of the ODP Site 654 (Tyrrhenian Sea, Wesetrn Mediterranean), Micropaleontology, 38(3), 279-288.

Fornaciari, E., 2000. Calcareous nannofossil biostratigraphy of the California Margin. In M. Lyle, I. Koizumi, C. Richter and T.C.Jr. Moore (eds), Proc. O.D.P., Sci. Results, 167, 3-40, College Station TX.

Freudenthal, T., 1969. Stratigraphy of Neogene deposits in the Khania province, Crete, with special reference to foraminifera of the family Planorbulinidae and the genus Heterostegina, Utrecht Micropal. Bull., 1, 1-208.

Frydas, D., and Keupp, H., 1996. Biostratigraphical results in Neogene deposits of NW Crete, Greece, based on calcareous nannofossils, Berliner geowiss. Abh., E 18, 169-189.

Frydas, D., Keupp, H., and Bellas, S., 1999. Biostratigraphical research in Late Neogene marine deposits of the Chania Province, western Crete, Greece, Berliner geowiss. Abh., E30, 55-67.

Hilgen, F.J., Krijgsman, W., Langereis, C.G., Lourens, L.J., Santarelli, A., and Zachariasse, W.J., 1995. Extending the astronomical (polarity) scale into the Miocene, Earth Planet. Sci. Lett., $136,495-510$.

Hilgen, F.J., Bissoli, L., Iaccarino, S., Krijgsman, W., Meijer, R., Negri, A., and Villa, G., 2000. Integrated stratigraphy and astrochronology of the Messinian GSSP at Qued Akrech (Atlantic Morocco), Earth Planet. Sci. Lett., 182, 237-251.

Huang, L., 1997. Calcareous nannofossil biostratigraphy in the Pearl River Mouth Basin, South China Sea and Neogene reticulofenestrids coccolith size distribution pattern, Mar. Micropaleontol., 32, 31-57.

Jackson, J., 1994. Active tectonics of the Aegean Region, Ann. Rev. Earth Planet. Sci., 22, 239271.

Kameo, K. and Bralower, T.J., 2000. Neogene calcareous nannofossil biostratigraphy of Sites 998, 999 and 1000, Caribbean Sea. In R.M. Leckie, H. Sigurdsson, G.D. Acton and G. Draper (eds), Proc. O.D.P., Sci. Results, 165, 3-17, College Station TX.

Keupp, H., Bellas, S., in collab. with Frydas, D., and Bartholdy, J., 2000. Neogene development of the sedimentary basins of NW Crete Island, Chania Prefecture, South Aegean Arc System (Greece), Berliner geowiss. Abh., E34, 3-117. 
Kontopoulos, N., Zellilidis, A., and Frydas, D., 1996. Late Neogene sedimentary and tectonostratigraphic evolution of northwestern Crete Island, Greece, $\mathrm{N}$. Jb. Geol. Paläont. Abh., 202(3), 287-311.

Krijgsman, W., Hilgen, F.J., Langereis, C.G., Santarelli, A., and Zachariasse, W.J., 1995. Late Miocene magnetostratigraphy, biostratigraphy and cyclostratigraphy in the Mediterranean, Earth Planet. Sci. Lett., 136, 475-494.

Krijgsman, W., Hilgen, F.J., Raffi, I., Sierro, F.J., and Wilson, D.S., 1999. Chranology, causes and progression of the Messinian salinity crisis, Nature, 400, 652-655.

Le Pichon, X., 1982. Landlocked oceanic basins and continental collision: the eastern Mediterranean as a case example. In K. Hsü (ed.), "Mountain Building processes", 201-211, London, Academic Press.

Lourens, L., Hilgen, F.J., Shackleton, N.J., Laskar, J., Wilson, D., 2004. The Neogene Period. In F.M. Gradstein, J.G. Ogg and A.G. Smith (eds), "A Geological Time Scale 2004", 409-440, Cambridge, Cambridge University Press.

Makris, J., 1978. The crust and upper mantle of the Aegean region from deep seismic soundings, Tectonophysics, 46, 269-284.

McKenzie, D., 1970. The plate tectonics of the Mediterranean region, Nature, 226, 239-243.

Marino, M., and Flores, J.A., 2002. Miocene to Pliocene calcareous nannofossil biostratigraphy at ODP Leg 177 Sites 1088 and 1090, Mar. Micropaleontol., 45, 291-307.

Martini, E., 1971. Standard Tertiary and Quaternary nannoplankton zonation. In Farinacci A. (ed.), Proc. II ${ }^{\text {nd }}$ Planktonic Conference, Roma (1970), Tecnoscienza, II, 739-777pp.

Martini, E., and Müller, C., 1986. Current Tertiary and Quaternary calcareous nannoplankton stratigraphy and correlations, Newsl. Stratigr., 16 (2), 99-112.

Mascle, J., Jongsma, D., Campredon, R., Dercourt, J., Glacon, G., Lecleath, A., Lyberis, N., Malod, J.A., and Mitropoulos, D., 1982. The Hellenic margin from eastern Crete to Rhodes: preliminary results, Tectonophysics, 86, 134-147.

Meulenkamp, J.E., Dermitzakis, M., Georgiadou-Dikeoulia, E., Jonkers, H.A., and Böger, H., 1979. Field Guide to the Neogene of Crete, Publ. Dept. Geol. Pal. Athens Univ., ser. A, 32, $1-32$.

Meulenkamp, J.E., Wortel, M.J.R., van Wamel, W.A., Spakman, W., and Hoogerduyn Strating, E., 1988. On the Hellenic subduction zone and the geodynamic evolution of Crete since the late Middle Miocene, Tectonophysics, 146, 203-215.

Meulenkamp, J.E., van der Zwaan, G.J., and van Wamel, W.A., 1994. On Late Miocene to Recent vertical motions in the Cretan segment of the Hellenic arc, Tectonophysics, 234, 53-72.

Negri, A., and Villa, G., 2000. Calcareous nannofossil biostratigraphy, biochronology and paleoecology at the Tortonian/Messinian boundary of the Faneromeni section (Crete), Palaeogeogr., Palaeoecol., Palaeoclimatol., 156(3-4), 195-209.

Okada, H., and Bukry, D., 1980. Supplementary modification and introduction of code numbers to the low-latitude coccolith biostratigraphic zonation (Bukry, 1973, 1975), Mar. Micropaleontol., 5(3), 321-325.

Raffi, I., and Flores, J.-A., 1995. Pleistocene through Miocene calcareous nannofossils from eastern Equatorial Pacific Ocean. In: N.G. Pisias, L.A. Mayer, T.R. Janecek, A. PalmerJulson and T.H. van Andel (eds), Proc. of the O.D.P., Sci. Results, 138, 233-286pp. College Station, TX. 
Raffi, I., Backman, J., and Rio, D., 1998. Evolutionary trends of calcareous nannofossils in the Late Neogene, Mar. Micropaleontol., 35, 17-41.

Raffi, I., Mozzato, C., Fornaciari, E., Hilgen, F.J., and Rio, D., 2003. Late Miocene calcareous nannofossil biostratigraphy and astrobiochronology for the Mediterranean region, Micropaleontology, 49(1), 1-26.

Raffi, I., Backman, J., Fornaciari, E., Pälike, H., Rio, D., Lourens, L., and Hilgen, F.J., 2006. A review of calcareous nannofossil astrobiochronology encompassing the past 25 million years, Quaternary Science Reviews, 25 (2006), 3113-3137.

Rio, D., Raffi, I., and Villa, G., 1990. Pliocene-Pleistocene calcareous nannofossil distribution patterns in the western mediterranean. In K.A. Kastens, J. Mascle, et al. (eds), Proc. O.D.P. Sci. Results, 107, 513-533pp, College Station, TX.

Schmidt, R.R., 1979. The calcareous nannofossils of the Potamidha section. In C.W. Drooger, et al., Problems of detailed biostratigraphic and magnetostratigraphic correlation in the Potamidha and Apostoli sections of Cretan Neogene, Utrecht Micropal. Bull., 21, 167-191.

Siesser, W.G., and de Kaenel, E.P., 1999. Neogene calcareous nannofossils: Western Mediterranean biostratigraphy and paleoclimatology. In R. Zahn, M.C. Comas and A. Klaus (eds), Proc. O.D.P. Sci. Results, 161, 223-237pp, College Station TX.

Sonnenfeld, P., 1985. Models of Upper Miocene Evaporitic genesis in the Mediterranean Region. In D.J. Stanley and F.-C. Wezel (eds), Geological Evolution of the Mediterranean Basin. 323-346pp, New York Berlin Heidelberg Tokyo, Springer-Verlag.

Theodoridis, S., 1984. Calcareous nannofossil biozonation of the Miocene and revision of the Helicoliths and Discoasters, Utrecht Micropal. Bull., 32, 1-271.

Young, J.R., 1990. Size variation of Neogene Reticulofenestra coccoliths from Indian Ocean DSDP Cores, J. Micropalaeontology, 9(1), 71-86.

Young, J., 1998. Neogene. In P. Bown (ed.), Calcareous Nannofossil Biostratigraphy. 225-265, London, Br. Micropaleontol. Soc. Publ.

Young, J.R., Flores, J.-A., and Wei, W., 1994. A summary chart of Neogene nannofossil magnetobiostratigraphy, Journal of Nannoplankton Research, 16, 21-27.

Wei, W., 2003. Upper Miocene nannofossil biostratigraphy and taxonomy of EXXON core CH3043-2 from the Gulf of Mexico, Journal of Nannoplankton Research, 25(1), 17-23.

Wortel, M.J.R., and Spakman, W., 1992. Structure and dynamics of subducted lithosphere in the Mediterranean region, Proc. K. Ned. Akad. Wetensch., 95, 325-347.

Wortel, M.J.R., and Spakman, W., 2000. Subduction and slab detachment in the MediterraneanCarpathian region, Science, 290, 1910-1917. 